\title{
DEVELOPMENT OF LEARNING MODEL SMASH VOLLEYBALL BASED MULTIPLE TRAINING IN FACULTY OF SPORT SCIENCES STATE UNIVERSITY OF MEDAN
}

\author{
Sofyan Hanif* Indra Kasih** \\ Statet University of akarta* \\ Statet University of Medan** \\ Sofyanhanif@unj.ac.id* \\ $\underline{\text { Indra_ksh@yahoo.co.id }} * *$
}

\begin{abstract}
This research is to development learning model smash volleyball based multiple training in State University of Medan. This method was research and development/R \& D proposed by Borg and Gall (2005). Based on trial results found, multiple based learning model increaset the skill of volley ball smash technique mastery at faculty of Sport Science of Medan Stated University. Multiple training based learning model is wearing 7 group, and 21 forms of learning. 21 models of learning based training deemed necessary multiple training applied in each learning smash volleyball. The results of this the new model of learning assessment indicators is more effective than the old one. The average effectiveness of the attitudes perfect/SS indicator is older models of learning is $78.33 \%$ and $86.67 \%$ of new models of learning. The average of effectiveness in $\mathrm{SW}$ indicator is older models of learning is $73.33 \%$ and $80.00 \%$ of new models of learning. The average effectiveness of the NT indicator on older models of learning is $71.67 \%$ and $85.00 \%$ of new models of learning. The average effectiveness of the indicators of $\mathrm{S}^{\wedge}$ on the old model of learning is $70.00 \%$ and $78.33 \%$ of new models of learning. Learning outcomes (average of all indicators) that reach increased from $73.33 \%$ to $82.50 \%$. It can be concluded that multiple training based learning model more effective than the old learning model.
\end{abstract}

Keyword: Development of Model-Based Learning Smash Volleyball

The highest public demand in educational services in each school make university improve the quality of graduates in order to answer the needs of sehrols. Various improvements have been made by the government in improving the quality of graduates, one is the improvement of the curriculum and educators increase the welfare budget of the welfare of teachers / lecturers. The efforts of the government was quite an impact on the desired changes, but the root of this issue has not been answered yet, Because the variety of other issues which are the emerging quality of graduates, are still less an impact on changes in the skills and competence of learners. The role of educator was replaced former athletes who do not graduate from college scorer educators, but service users believe the former athlete can give a better change to the learners._The root of this problem must be solved by improving the quality of graduates, such as improving the system of teaching.

The low quality of college graduates score education personnel can be inferred from the number of complaints from people who immediately see shortcomings in the teaching of competence skills taught motion. This can be seen from two things: (1) The educators have weaknesses in terms of mimicking the movement skills in a ball game of volleyball in particular provide reinforcement of techniques smash in volleyball lesson. (2) Lack of knowledge in the application of learning models make supporting the ease in creating competency goals.

The weaknesses lines of the need for improvement of the quality of graduates by making improvements on all fronts. One of them is the improvement of the learning model in supporting the improvement of the competence of learners. This effort is aligned with efforts to support the government to improve educational purposes Indonesia and cultivate a healthy lifestyle through proper movement skills to support a sporting activity and health in instilling values: attitude, mental, sportsmanship, emotionally and socially in life's daily habits the day

is to provide a form of education and teaching more innovative for learners in order to support the objectives of the creation of motion better.

Teachers / Lecturers as an educator has the duty to carry out the teaching and learning process. Teachers / Lecturers should have a strategy to take place optimally. The use of strategies in teaching 
and learning activities is necessary to facilitate the learning process. Without a strategy, learning process will not be directed so that the learning objectives that have been set can not take place effectively and efficiently.

To answer the needs more profound changes both in the model of teaching, infrastructure and teaching patterns. The change should be able to overcome the problems which as an obstacle revolution as one of improvements to the needs of the graduates.

Based on this analogy, the model of teaching is a kind of blueprint for teaching. As a blueprint, provide structure and direction for engineers, direction for teachers / lecturers. But the blueprint does not dictate all actions of an engineer and a model is not able to dictate all actions of a teacher / lecturer. The blueprint is not a substitute for basic engineering skills as well as teaching models.

The models can not replace the qualities of teachers, such as professional students, and the ability to make decisions in emergency situations. The model is actually a form to help teachers make their teaching systematically and efficiently, so that will achieve the goal of learning in three domains: cognitive domain, psychomotor domain, affective domain.

\section{METHOD}

This study focused on development of a learning model, the approach and methods used in this study is a research and development (research and development / R \& D), with the design of the chosen development is referring to the development proposed by Borg and Gall, 2005, which comprises of the following.



Figure 1. Model Development Phase Borg and Gall (Borg, W.R. \& Gall, M.D., 2005: 590)

The development model of learning is done through three stages: (1) the stage of identification and need analysis, (2) the development stage design and draft model of multiple training, and (3) the testing phase (expert review and testing). Small group trial conducted on students majoring in health physical education and recreation 2014 regular $A B$ class with 15 people and a large group trials conducted with 56. People data was collected using documentation, testing, non-tests, questionnaires, and observations. Data analysis was performed by descriptive, qualitative and quantitative. In the test phase and test a small group of experts, validity, practicality, and effectiveness of the model, analyzed descriptively with 
the following criteria. In the large group trials (field tests) that is in Phase III evaluation, testing was conducted to study the experiment, the experimental design.

before-after or one-group-pretest-posttest design as follows.

$\mathrm{Oi} \quad \mathrm{O} 2$

Figure 2. Design of experiments before-after (one-group -pretest-posttest design) (Sugiyono, 2008:111)

\section{Description:}

1 = sample experimental group pretest $\mathrm{X}$

$=$ Group Experiments

2 = sample experimental group posttest

Validation, evaluation and revision of the model
a. Assessing experts
b. One-to-two trial
c. Small group trial
d. Large group trials

Before the subjects subjected to treatment first, we as researchers conducted observations in the form of pre-test $(\mathrm{O} 1)$ and then do the treatment smash technique $(\mathrm{X})$ and there after held observation or post-test $(\mathrm{O} 2)$. (3) seek the average score of the pre-test and post-test, and then compare both through statistical methods (t-test) to determine whether there is significant influence of the use of the learning model. Other data in the form of field notes and documentation must be in the main trial so that no feedback (feedback) used for repairing and improving learning model in the development of the next until the optimization is the ultimate form that is ready for use. To see Pearson Correlation coefficient (r), the data processed using SPSS 17.0.

Development of instruments in this study conducted in conjunction with the development of draft model. The validity of the instrument is measured based on the correspondence between aspects of the instrument with the data to be collected through the opinions of the validator. Instrument reliability is measured by the level of suitability of the opinion of the validator of the aspects that exist on the instrument. As for achievement test sought reliability level with test-retest technique. To see Pearson Correlation coefficient (r), the data processed using SPSS 17.0.

\section{RESULTS}

Results of this study in the form of book learning model based multiple smash volleyball training. Research done initial research that is useful to get information about movement of a volleyball smash undertaken by students.

Development learning model smash volleyball-based multiple training methods development Borg and Gall, which consists of 10 steps and is divided into three phases globally, namely: (1) the stage of identification and need analysis, (2) the development stage design and draft learning model smash ball volleyball multiple-based training, (3) the testing phase (review experts, small group testing, and field testing).

The general purpose of this research is to develop a learning model, which the modify an existing model of learning (the old model of learning). 
Table 1. Existing Learning Model

\begin{tabular}{|r|l|}
\hline No & \\
\hline 1 & Jump Chest \\
\hline 2 & Step and Jump \\
\hline 3 & Throwing a ball at the floor \\
\hline 4 & Throw hit toward a friend \\
\hline 5 & Smash by using the net \\
\hline
\end{tabular}

Table 2. Needs Analysis In Smash

\begin{tabular}{|c|l|l|}
\hline No & \multicolumn{1}{|c|}{ Stages Smash } & \multicolumn{1}{c|}{ Needs } \\
\hline 1 & Attitude prefix. Run-Up (run approached) & $\begin{array}{l}\text { 1. Coordination ankle } \\
\text { 2. The strength of leg muscles } \\
\text { 3. Agility } \\
\text { 4. Speed }\end{array}$ \\
\hline 2 & Jump Take Of ( Off Shelf) & $\begin{array}{l}\text { 1. Coordination ankle } \\
\text { 2. Swing arms } \\
\text { 3. Vertical jump } \\
\text { 4. Flexibility }\end{array}$ \\
\hline 3 & Hit (When hitting flyng) & $\begin{array}{l}\text { 1. Flexibility of the body } \\
\text { 2. hand eye coordination } \\
\text { 3. Angle ideal weight by weight } \\
\text { 4. inaccuracy of hand }\end{array}$ \\
\hline 4 & Landing (landed) & $\begin{array}{l}\text { 1. Coordination ankle } \\
\text { 2. The strength of leg muscles } \\
\text { 3. balance }\end{array}$ \\
\hline
\end{tabular}

The model is developed into a product development model of learning basic techniques smash volleyball with respect to the needs of basic techniques smash are two objectives to be disclosed in a preliminary study, namely (1) determine the implementation process of learning the course of volleyball in the majors PJKR Faculty of Sport Science, State University of Medan. (2) how important the development of the learning model smash- based multiple training in the process of learning the course volleyball. The general objective above and then became the basis of researchers conducted a preliminary study using research instrument in the form of a questionnaire to the lecturers volleyball, as well as conducting a survey when the implementation of learning volleyball in the field. Another thing how important the development of a smash-based learning model will be developed multiple training researchers to study the implementation of volleyball.

Preliminary design in the planning model development learning model smash volleyball-based multiple training refers to a pattern that has been there are 5 models later in the analysis in accordance with the needs of the smash which had 4 stages in the implementation of the smash namely: Attitudes perfect (SS), Attitude prefix (SA), Introduction to the ball (PB) and attitude end (SA). From the analysis of the needs it was developed into 21 models of learning in order to support the mastery of technique smash in volleyball.Based on the conclusion, the differences between the old model of learning models to study new models (models of multiple training exercises). The effectiveness of the development of the learning model learning outcomes old and new models have increased from $73.33 \%$ to $82.50 \%$. Questionnaire Assessment of learning design has a 27 point statements. Results of the questionnaire assessment carried out by the students good at learning new model and the old model can be seen as follows: that the old model of learning design effectiveness by $71.30 \%$ and amounted to $82.35 \%$ of new models. Draft Assessment Questionnaire Multiple learning training model has amounted to $76.5 \%$ effectiveness. Assessment Questionnaire Multiple learning model training effectiveness assessment 
results and assessment questionnaires learning model has multiple training effectiveness by $89.70 \%$.

Volleyball smash performance of the experimental group post test indicator SS, SW, NT and SA. Assessment of learning outcomes of each indicator learning new model is more effective than the old model of learning. Learning outcomes (average of the overall indicator) which increased from $66.74 \%$ to $88.84 \%$. Therefore, a new model of learning is more effective than the old model of learning. Questionnaire assessment of the learning design with 18 point statement. The results of the questionnaire assessment carried out by the students good at learning new model and the old model shows the old model of learning design effectiveness by $76.5 \%$ and amounted to $87.28 \%$ of new models . The Draft of Assessment model of multiple training results of the assessment indicator on assessment questionnaire learning model has multiple training effectiveness of 91.2\%. Assessment Questionnaire multiple training learning model has 22-point declaration. And the effectiveness has amounted to $94.03 \%$.

\section{DISCUSSION}

The multiple learning model training have valid criteria and effective. This means that the model-based exercises multiple training is a model to design a model in mastery of technique smash volleyball that is based on the concept of a strong theoretical, components of the model are related to each other, can be implemented in practice in the classroom / field, can improve student achievement in subjects volleyball. Development learning model smash volleyball multiple training is learning based on the station or circuit, which consists of several stations arranged in a circle so that the muscle groups working sequentially from station to another station. Learning should be chosen to change the muscle groups, with cultivated better and faster recovery. Rest interval between 60-90 seconds to 1-3 minutes between the post. In the implementation of teaching learning model based multiple smash volleyball training itself has a syntax consists of six phases. Each phase will have relevance steps of learning.
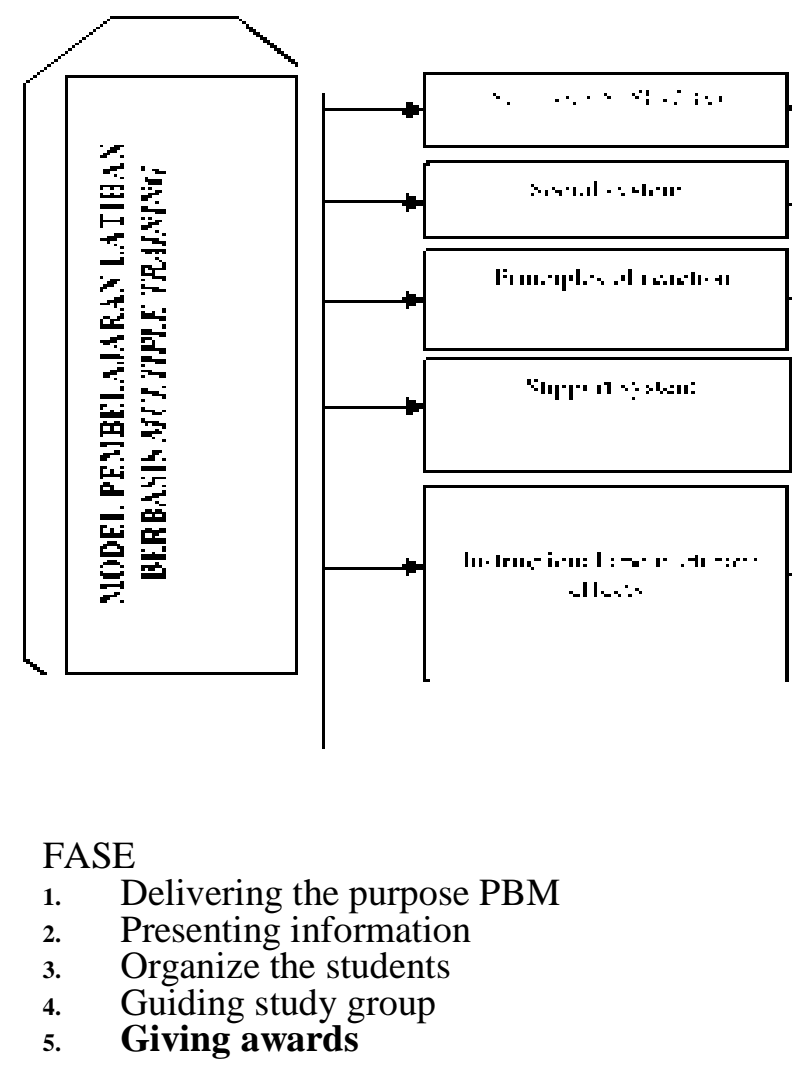

Develop an atmosphere of democracy, motivation, positive personal relationships, directing and split the group, facilitating students and groups, mutual correction and mutual respect, monitoring 
student activities Textbooks, learning tools such as syllabi and lesson plans, media and learning tools Impact instructional: the ability in the construction of knowledge, solve the problems, and mastery of subject matter. Impact accompanist: mutual respect for the opinion of friends / humble. A positive attitude in the course smash, have the independence, self-confident, honest, helpful friend, a cooperative spirit, capable of working together, a commitment to the group as well as the critical ability

The and imitiates table description can be explained as follows:

1. Syntax (Syntax)

The activities syntax shows the entire sequence or the flow of the lesson. Syntax shows the types undertaken by teachers. Syntax determines what should be done by the students. According to the learning steps and the sequence of tasks must be performed by students. Decrypt the syntax in order activity called phase; each model has different phase groove. The following described learning phase based on exercise training: 1) Prepare the purpose of learning and motivating students. 2) Presenting the lessons. 3) Organizing students in groups. 4) Working groups and study guide. 5) Awarding. 6) Evaluation. The following syntax multiple learning model training. In the implementation of multiple training based learning, any material contained in each set of learning has linkages to the mastery of technique smash volleyball. There are 21 forms of mixed learning model in multiple training learning, where learning model made from 21 to 7 learning groups consisting of three forms of learning models therein. Each group consisted of three students who perform the movement in accordance with the specified time, then any movement there are learners must feel all learning models trained, so that a third students feel that there are three models of learning. In the implementation of model practice multiple training, 21 learning model is divided into seven groups of learning activities and all the learning model is linked to increase in engineering skills smash volleyball and seven groups alternate between series one to series seventh resulting in a symbiotic mutualism of all the groups that in improving technical skills smash volleyball.

Table 3. Multiple learning training

\begin{tabular}{|c|c|c|}
\hline No & Team work & Instruction was given \\
\hline 1 & Group A consists of 3 series & $\begin{array}{l}\text { 1. Learning for technical rubber whip hand in smash } \\
\text { Throw the ball with a whip hand towards a friend } \\
\text { 2. Throw the ball against the floor with the whip hand }\end{array}$ \\
\hline 2 & Group B consists of 3 series & $\begin{array}{l}\text { 1. Learning to sit while hitting the ball with the help of } \\
\text { friend. } \\
\text { 2. Back-up while hitting the ball } \\
\end{array}$ \\
\hline 3 & Group C consists of 3 series & $\begin{array}{l}\text { 1. Knead the ball while walking towards of a friend } \\
\text { 2. Hit the ball towards the middle of the floor of a friend }\end{array}$ \\
\hline 4 & Group D consists of 3 series & $\begin{array}{l}\text { 1. Hitting the ball in pairs by throwing himself towards } \\
\text { friends without jumping. } \\
\text { 2. Hit the ball to the floor of the middle of the feed itself } \\
\text { towards learners with jumps. } \\
\text { 3. Hit the ball to the floor with the help of a friend } \\
\text { anerand without immnina }\end{array}$ \\
\hline 5 & Group E consists of 3 series & $\begin{array}{l}\text { 1. Smash floor to pair up with a friend to help throw } \\
\text { jumps. } \\
\text { 2. Stradell while hitting a ball held by his friend } \\
\text { 3. Combination touched the ball ran back and jumped up }\end{array}$ \\
\hline 6 & Group F consists of 3 series & $\begin{array}{l}\text { 1. Ruler for learning the swing arm combination with } \\
\text { hitting the ball } \\
\text { 2. Ruler learning body flexibility combined with hitting } \\
\text { the ball }\end{array}$ \\
\hline 7 & Group $\mathrm{G}$ consists of 3 series & $\begin{array}{l}\text { 1. Smash ball hanging } \\
\text { 2. Smash with the help Boks } \\
\text { 3. Smash over the net }\end{array}$ \\
\hline
\end{tabular}


Results of this study was to accommodate the motion of the learning objectives, view of the theory of learning is a process to provide real experience for students. There are three potential should be modified. Psychological processes associated with cognitive processes to distinguish, analyze, interpret, and integrate sensory information input, including:

a. Cognitive domain

Paull Eggen / Don Kauchak Strategy and Learning Model states that the cognitive domain as applied to the study of the behavior of the movement involves the relationship between the mind (knowledge) with the body. Pos learning created in multiple learning training contained an understanding as to what implementation techniques in support of the motion smash skills so that learners acquire new knowledge about how the implementation of the right moves in learning to understand the movement technique smash.

The knowledge gained will be a new experience in making hearing, vision and execution are applied in practice exercises basic techniques smash. Grooves of execution that makes the knowledge stored in memory and will be stored for a long time and at last slowly these movements will be automation in its implementation.

b. Psychomotor domain

Paull Eggen / Don Kauchak Strategy and Learning Model declare psychomotor domain is one of the destination domain of education with respect to motion and control body movements. Movement and control of body movement is the nature psychomotor activity. All forms of movement exhibited learners is about learning the motion, meaning that the learning model of multiple training exercises contains learning that involves members of the body, in this case the students had been trained how to do a proper motion study for the achievement of the objectives of the learning itself.

The function of the study of motion give lovely gesture and the right technique and make the function of studying the motion itself is reached, and vice versa when studying the motion done incorrectly both technically and the motion will result in movement of the smash was irregular and not reaching effectiveness of motion better.

\section{c. Affective domain}

Paull Eggen / Don Kauchak Strategy and Learning Model, domain affective states such as those associated with the study of human movement involves feelings and emotions as applied to themselves and other people through the motions. In the implementation of multiple training exercises learning wear pattern learning implementation on any form of movement of his post. Learners will provide observations of learners who carry out the study, so the event of a communication between learners with each other against the motion carried is already in line with the guidelines or not. When an error occurs, the movement of learners observe and provide insight in accordance with the guidelines.

\section{CONCLUSIONS}

Based on data obtained from the test results to experts, small group testing, field testing and product testing, as well as the discussion of the results of research can be concluded as follows. (1) The development of training models smash volleyball multiple training has fulfilled the operational criteria for a model of learning which are: syntax contained therein social system, prinsiplay reaction, system support and accompaniment. (2) The results of the model development exercise training has qualified multiple validity, homogeneity, normality, effectiveness and development model of multiple training exercises have been able to improve student results PJKR regular Faukultas Sport Science University of Medan. Basically learning model development exercise volleyball multiple training has met the criteria 
requirements the application of a learning model: syntax (syntax), the social system (social system). Reaction principle (principles of reaction). System support (support system), as well as the effects and impact instrusional accompaniment (instructional and naturant effects). So that these models can smash me improve skills of volleyball in the majors PJKR class A and B FIK Unimed. In general, the lecturer urgently need a wide range of varied learning model smash particularly the use of simple tools and various forms of basic motion in improving basic techniques in accordance with the rules smash. The pattern of learning during this monotonous and stagnant can be overcome by the application development learning model smash volleyball multiple exercise training, in order to reach the goal of teaching itself. Based on the phasing of research and development that produces products such as teaching models smash volleyball at FIK Unimed, it was found that overall the product is effectively carried out by a lecturer of the course volleyball. This can be seen from the results of the discussion of the results of product testing, that in terms of the existence of the product, usefulness, practicality, the level of efficiency of time, effort, cost and level of clarity that this product is the right solution in facing the problems experienced educators in improving the skills smash volleyball.

\section{REFERENCES}

Borg. W. R \& Gall, M. D, Education Research: And Introduction, Fifh education. Newyork: Long, 1989.

Bruce Joyce,Marsha Weil. Models of Teaching.Second Edition. USA: Prentice-Hall, 1980.

Dini Rodisni. Perencanaan Pembelajaran dalam Pendidikan Jasmani dan Kesehatan, 2013.

Gay, L.R. Educational Evaluation and Measurement: Com-petencies for Analysis and Application.Second edition. New York: Macmillan Publishing Compan, 1991.

Isriani Hardini dan Dewi Pusputa, Strategi Pembelajaran Terpadu.Tori, konsef \& implementasi, 2012.

Jamaluddin, Pengembangan Model Pembelajaran Pendidikan Jasmani Olahraga dan Kesehatan Berbasis PAKKEM. Disertasi UNJ, 2014.

Ketut Yoda.Pengembangan Model Pembelajaran Penjasorkes Berbasis Kearifan Lokal (PPBKL) dI SMP.Disertasi UNJ 2015.

Nana Syaodih Sukmadinata, Metode Penelitian Pendidikan, Bandung: Remaja Rosdakarya, 2005.

Paul Eggen, Don Kauchak, Strategi dan Model Pembelajaran.Indeks 2012

Sugiono.Metode Penelitian Kuantitatif Kualitatif dan R\&D Bandung: Alfabeta, 2010.

Trianto. Mendesain Model Pembelajaran Inovatif-Progresif: Konsef, landasan, dan Implementasinya pada kurikulum Tingkat satuan pendidikan (KTSP). Jakarta: Kencana, 2011. 